\title{
The relationships between leptin gene polymorphism and some performance traits in Simmental and Brown Swiss cattle
}

\section{Tugba Atalay}

Ataturk University: Ataturk Universitesi

Memiş Özdemir ( $\sim$ ozdemirm@atauni.edu.tr)

Ataturk University, Faculty of Agriculture

\section{Research Article}

Keywords: Leptin, polymorphism, performance traits, Simmental, Brown Swiss

Posted Date: November 29th, 2021

DOI: https://doi.org/10.21203/rs.3.rs-1073960/v1

License: (c) (i) This work is licensed under a Creative Commons Attribution 4.0 International License. Read Full License

Version of Record: A version of this preprint was published at Turkish Journal of Agriculture - Food Science and Technology on November 26th, 2022. See the published version at https://doi.org/10.24925/turjaf.v10i12.2405-2409.5179. 


\section{Abstract}

This study was carried out to determine the genotype and allele frequencies and association between the Leptin gene Sau3AI polymorphism and some performance characteristics in Simmental $(n=60)$ and Brown Swiss $(n=62)$ breed cattle raised in the province of Erzurum, Turkey. In the study, leptin/Sau3AI gene polymorphisms in DNA isolated from blood samples obtained from Simmental and Brown Swiss cattle were determined using PCR-RFLP method. As genotype frequencies of leptin/Sau3AI gene in the population, in Brown Swiss cattle, $88,7 \%$ with genotype $A A, 9,7 \%$ with $A B$ and $1,6 \%$ with $B B$ genotypes were determined, Simmental breed cattle, $78,3 \%$ with genotype $A A, 16,7 \%$ with $A B$ and with $5,0 \%$ BB genotypes were determined. $A A$ genotype frequencies were the highest in the population, and those with BB genotypes had the lowest frequency in both breeds. When the population was examined in terms of allele frequencies, the A allele was 0,87 and B allele was 0,13 in the Simmental cattle, and the A allele was 0,94 and B allele was 0,06 in the Brown Swiss breed. According to Hardy-Weinberg genetic balance test, the distribution of genotype frequencies was balanced $(P>0.05)$ in the Brown Swiss breed but not in the Simmental breed in the population studied. As a result of the analysis performed in the Simmental breed, the general averages were found to be $5422,4 \pm 1901,74 \mathrm{~kg}$ for actual milk yield, $5626,6 \pm 1475,85 \mathrm{~kg}$ for 305 -day milk yield, $298,7 \pm 84,80$ days for lactation duration and $18,5 \pm 4,84 \mathrm{~kg}$ for daily milk yield. According to the statistical analysis results, the effect of genotype on the actual milk yield during lactation, lactation duration and daily milk yield was significant. As a result of the analysis made in the Brown Swiss breed, the general averages were 3917,8 $\pm 1584,38 \mathrm{~kg}$ for actual milk yield, 4614,3 $\pm 982,62 \mathrm{~kg}$ for 305 days milk yield, $254.9 \pm 99.88$ days for lactation duration and $16,0 \pm 3,82 \mathrm{~kg}$ for daily milk yield. According to the statistical analysis results, the effect of genotype on performance characteristics was insignificant in Simmental and Brown Swiss cattle.

\section{Introduction}

The livestock sector, which has an important place in meeting the animal-based nutrient needs of human beings, shows a rapid development with the effect of technology and other factors. In parallel with the technological developments, new breeding methods are applied to meet the demand for animal products due to population growth. Two factors are effective on the phenotypic value of animals in terms of any trait. One of them is genotype and the other is environment (Akman, 2016). While determining the quantitative characteristics of animals in the livestock sector, it is impossible to determine genotypes with ideal alleles by looking only at phenotypes, but phenotypic values do not always reflect genotypic values. Creating the superior phenotype in animals is only possible by identifying good and efficient genes that affect the character, bringing together the desired genes in the genotype and benefiting from the interaction between genes.

One of the candidate genes for marker assisted selection is the leptin gene. The leptin gene is expressed in a variety of tissues, including adipose tissue, placenta, mammary glands, skeletal muscles, gastric mucosa, brain, and pituitary glands. Leptin appears to have a major effect in coordinating whole body energy metabolism and can be classified as a metabolism modifier (Houseknecht et al., 1998). In cattle, the leptin gene is located on the 4th chromosome and consists of three exons (Pomp et al. 1997). Leptin is a $16 \mathrm{kDa}$ protein synthesized by adipose tissue and plays a role in the regulation of feed intake, energy balance, fertility and immune functions (Fruhbeck et al., 1998).

The leptin gene is associated with single nucleotide polymorphisms and also with many quantitative characters such as carcass fat, feed consumption, and milk yield (Kök et al., 2015). Polymorphisms in the leptin gene have been associated with milk performance (Liefers et al., 2002; Heravi et al., 2006), increased perinatal mortality in dairy products (Brickell et al., 2010), calf birth and weaning weights in beef and dairy products (Almeida et al., 2003; Nkrumah et al., 2005; DeVuyst et al., 2008) and reproductive characteristics in dairy cattle, including gestational age (Komisarek and Antkowiak, 2007).

Leptin is a protein that has an important role in the realization of many functions in animals. In addition to taking part in the metabolism and growth of animals, leptin has important duties on features such as feed utilization, energy metabolism and reproductive efficiency. The leptin gene, which has an important role in all of these economically important mechanisms, is an excellent candidate gene for studies of polymorphism and association of these polymorphisms with economic characteristics 
(Ninov et al., 2008; Özdemir, 2008). Therefore, the objective of the present investigation was to investigate the genotypic structures of the Leptin gene Sau3AI (LEP/Sau3AI) polymorphism, to determine the genotype and allele frequencies of the cattle and to associate these genotypes with some performance characteristics in Simmental and Brown Swiss cows in Turkey.

\section{Material And Methods}

The animal material of this research consisted of genomic DNA samples obtained from blood samples taken for previous studies (Ünal, 2020) of 62 Brown Swiss and 60 Simmental breeds, which were raised in two different farms intensively produced in Erzurum.

The Leptin gene specific primers (5'-TCT TAA GCT AGT CAG GTT CCA CAA GGT-3' and 5'-TGC TCC ACG CAG GTG AGC AAG$3^{\prime}$ ) designed by Ozdemir (2011), were used to amplify a 495 bp Fragment in cattle. Amplification reactions were performed in a final volume $25 \mu \mathrm{l}$ containing approximately $3 \mu \mathrm{l}$ genomic DNA, $1 \mu \mathrm{l}$ dNTP (D7595: Sigma, St. Louis, MO, USA), $0.5 \mathrm{U}$ of Taq DNA Polymerase (D1806: Sigma, St. Louis, MO, USA), $1 \mu \mathrm{M}$ of each Primer, $3 \mu$ l of 10x PCR Buffer (100 mM Tris- $\mathrm{HCl}, \mathrm{pH} 8.3$, $500 \mathrm{mM} \mathrm{KCl}, 15 \mathrm{mM} \mathrm{MgCl} 2$ and $0.01 \%$ gelatin), $1 \mu \mathrm{l}$ of $25 \mathrm{mM} \mathrm{MgCl} 2$ and ddH2O. After $10 \mu \mathrm{l}$ mineral oil in tubes, PCR amplifications were performed in $2 \mathrm{~min}$ at $94^{\circ} \mathrm{C}, 30$ cycles of $45 \mathrm{~s}$ at 94,60 and $72^{\circ} \mathrm{C}$, which $\mathrm{w}$ as followed by final extension at $72^{\circ} \mathrm{C}$ for $5 \mathrm{~min}$. After the PCR process, $8 \mu \mathrm{l}$ of each PCR product was run on a $1.2 \%$ agarose gel at $80 \mathrm{~V}$ for 25 minutes to determine whether amplification occurred. Products with completed amplifications were stored in an environment at $-20^{\circ} \mathrm{C}$ until the next step. To genotype animals for the RFLP, 7-9 $\mu$ I PCR reaction mix was used for Sau3A1 enzyme digestion which was performed in $20 \mu \mathrm{l}$ volume in $0.2 \mathrm{ml}$ sterilized eppendorf tubes and incubated at $37^{\circ} \mathrm{C}, 12 \mathrm{~h}$. Each $20 \mu \mathrm{l}$ digestion mix was electrophoresed in $2.5 \%$ agarose gel at $30 \mathrm{~V}$ for $2.5 \mathrm{~h}$ and DNA was visualized by staining with ethidium bromide under UV light. A standard DNA marker (P1473: Sigma, St. Louis, MO, USA) was used. The digested AA PCR product exhibited two fragments of 299 and 196 bp. For the BB genotype exhibited 214, 196 and 85 bp (Table 1). For each cattle breed, Leptin allele frequencies were determined by gene counting. The Chi-square $\left(X^{2}\right)$ test was used to check whether the populations were in Hardy-Weinberg equilibrium or not.

In the statistical analysis; Yield records of 60 Simmental and 62 Brown Swiss animals raised in private enterprises in Erzurum were used and milk yield characteristics such as actual milk yield, 305-day milk yield, lactation period and daily milk yield were examined as performance characteristics. Intermittent environmental factors such as genotype, lactation order and calving season, which are effective on these yield traits, are emphasized.

According to the yield characteristics in the study, the following statistical model was used.

$Y_{i j k l}: \mu+a_{i}+b_{j}+c_{k}+e_{i j k l}$

$\mathrm{Y}_{\mathrm{ijk}}$ : The value of any Simmental or Brown Swiss cow in terms of performance (actual milk yield, 305-day milk yield, lactation period and daily milk yield) characteristics considered,

$\mu$ : Population mean

$a_{i}:$ i. genotype effect (i:3; $\left.1: A A ; 2: A B ; 3: B B\right)$

$b_{j}$; j. effect of lactation order (2.-7),

$c_{k}$ : k. effect of calving season (k:2; 1: Kış ve ilkbahar, 2: Yaz ve Sonbahar)

$e_{i j k l}:$ I.. Marginal error.

In the model used, all the factors except the error were considered constant, and the error was accepted as randomized. 


\section{Result And Discussion}

DNA samples obtained from the blood of Simmental and Brown Swiss cattle were carried out on a 1.2\% agarose gel by PCR and PCR products were obtained. Figure 1 shows the agarose gel image of the PCR products.

DNA samples obtained from Simmental and Brown Swiss cattle were amplified in a PCR device and as a result of cutting the DNA fragments of 495 bp long PCR product with restriction enzyme, 299 and 196 bp for AA genotype, 214, 196 and 85 bp for BB genotype and 299 for AB genotype. It has been determined that they form 214, 196 and 85 bp long bands.

Genotypic and allele gene frequencies of breeds are presented in Table 1, and Hardy-Weinberg genetic equilibrium test results are presented in Table 2.

When the population was examined in terms of allele frequencies, it was determined that the A allele was at the frequency of 0.87 and the B allele was at the frequency of 0.13 in Simmental cattle, while the A allele was at the frequency of 0.94 and the $B$ allele at the frequency of 0.06 in Browns cattle (Table 2). The leptin gene $A A, A B$ and BB genotype frequencies were found to be $78.3 \%, 16.7 \%$ and $5.0 \%$ in Simmental, $88.7 \%, 9.7 \%$ and $1.6 \%$ in Brown Swiss, respectively. In both breeds, AA genotype frequencies were observed to be the highest in the population, while BB genotypes had the lowest frequency (Table 3).

Considering other similar studies; Pomp et al., (1997), Rasor et al., (2002), Javanmard et al., 2004, Leifers et al., (2002), Leifers et al., (2003), Javanmard et al., (2005) ), Javanmard et al., 2010, Öztabak et al. 2010, Kulig et al., (2010), Aytekin, (2011) the allele frequencies stated in their study and the allele frequencies in the study are in harmony.

According to the Hardy-Weinberg genetic balance test performed for both breeds, LEP/Sau3Al gene polymorphism in Brown Swiss breed was in equilibrium $\left(X^{2}=2.44 ; P>0.05\right)$, while in Simmental breed $\left(X^{2}=4.67 ; P<0.05\right)$ was not found to be in equilibrium. This situation in Simmental cattle; It is thought that the increase in certain genotypes in the population is prevented or caused by sampling error due to the absence of chance mating in breeding studies.

The least squares means and standard errors of the Leptin gene polymorphic structure in terms of some yield characteristics in Brown Swiss and Simmental cattle are given in Table 4.

When the averages of daily milk yield, actual milk yield and 305-day milk yields of LEP/Sau3Al genotype were examined, it was determined that the highest average was the AA genotype in the Brown Swiss and the AB genotype in the Simmental. The effect of LEP/Sau3Al genotype on daily milk yield, actual milk yield and 305-day milk yield was found to be insignificant $(P>0.05)$ in both breeds. In the study, it was determined that cows with BB genotype had a longer lactation period for both breeds, while the effect of LEP/Sau3Al genotype on lactation period was found to be insignificant $(P<0.05)$ in both breeds. That have been reported similar results for milk yields by Madeja et al., (2004), on 117 Polish Black and White bulls, by Gürses (2010), on Jersey, Brown Swiss, Holstein, Eastern Anatolian Red and Native Black breeds, by Alashawkany et al., (2008) on Holstein breeds. However, Moussavi et al., (2006) found that the effect of LEP/Sau3Al gene on 305-day milk yield was significant in their study on 238 Iranian Holsteins. Also, It was reported that in study on 595 Holstein cows (Liefers et al., 2002) , AB genotype cows had higher daily milk yield than AA genotype cows and, in study on Brown Swiss breed (Ghazanfari et al., 2006), cows with AA genotype had higher yield and lactation period than BB genotype.

\section{Conclusion}

As a result of the research, in order to determine the LEP gene Sau3AI polymorphism, the genotype and allele frequencies of each cattle breed were determined by using the PCR-RFLP method from genomic DNAs obtained from Simmental and Brown Swiss cattle. It was seen that the results obtained were sufficient to reveal the genotype and allele frequencies of the populations and as a result of the correlation analysis, the effect of the LEP/Sau3AI polymorphism on the performance characteristics related to milk yield was insignificant $(P>0.05)$ in both breeds. It is thought that demonstrating the usability of such studies in the breeding of cattle and applying similar studies in different breeds, different regions and larger populations will provide great contributions and new opportunities to the development of animal husbandry.

Page $4 / 9$ 


\section{Declarations}

Acknowledgements We thank Prof.Dr.Armagan HAYIRLI and managers of herd for supplying the this study.

Author contribution Material preparation, data collection, and analysis were performed by all authors. The preparation of the manuscript and the later version was written by Memis Ozdemir.

Funding It did not receive any financial support.

Availability of data and material The data sets generated and/or analyzed during the current study are available through the corresponding author upon reasonable request.

Code availability Not applicable.

Ethics approval Since ethical approval was obtained in the study of blood samples taken from Simmental cattle by Gülüzar Sengul (Ataturk University, Faculty of Agriculture, Ethics Committee Head, 2018/1), ethical approval was not required for this study.

Consent to participate Not applicable.

Consent for publication Not applicable.

Conflict of interest The authors declare no competing interests.

\section{References}

Akman, N., 2016. Hayvan Islahı. Ankara Üniv. Ziraat Fakültesi Zootekni Bölümü.

http://zootekni.agri.ankara.edu.tr/wp_content/uploads/sites/353/2016/03/HYB_ISLAH_2016.pdf

Alashawkany, A.R., Shahroudi, F.E., Nassiry, M.R., Moussavi, A.H., Heydarpour, M., Sadeghi, B., 2008. Association of SNP in the exon II of leptin gene with milk and reproduction raits in Holstein Iranian Cows. Biotechnology 7, 347-350.

Almeida, S.E., Almeida, E.A., Moraes, J.C.F., Weimer, T., 2003. Molecular marker in the LEP gene and reproductive performance of beef cattle. Journal of Animal Breeding and Genetics, 120, 106-113.

Aytekin, I.., 2011. Konuklar Tarım İşletmesinde Yetiştirilen Esmer İsviçre Sığırlarda Leptin ve PiT-1 Geni Polimorfızmleri ile Süt Verimi ve Kompozisyonu Arasındaki Illişkiler, Doktora tezi, Konya: Selçuk Üniversitesi Fen Bilimleri Enstitüsü Zootekni Anabilim Dalı, Konya

Brickell, J.S., Pollott, G.E., Clempson, A.M., Otter N., Wathes, D.C., 2010. Polymorphisms in the bovine leptin gene associated with perinatal mortality in Holstein-Friesian heifers. Jornal of Dairy Science, 93, 340-347.

DeVuyst, E.A., Bauer, M.L., Cheng, .FC., Mitchell, J., Larson, D., 2008. The impact of a leptin gene SNP on beef calf weaning weights. Animal Genetics, 39, 284-286.

Fruhbeck, G., Jebb, S.A., Prentice, A.M., 1998. Leptin: Physiology and pathophysiology. Journal of Clinic Physiology, 18, $399-$ 419.

Ghazanfari, S., Nassiry, M., Moussavi, A.H., 2006, Polymorphism in gene leptin and its relationship to milk production and reproduction traits in Brown Swiss cows, Proceedings of The British Society of Animal Science, Poster Presentation,

Gürses, M., 2010. Bazı Kültür ve Yerli Sığır Irklarında Leptin Geni Polimorfızmlerinin Belirlenmesi ve Süt Verimi ile Bileşimi Üzerine Etkileri, Doktora Tezi, Elâzığ: Fırat Üniversitesi Sağılk Bilimleri Enstitüsü Zootekni Anabilim Dalı. 
Houseknech, K.L., Baile, C.A., Matteri, R.L., Spurlock, M. E., 1998. The biology of leptin: a review. J Animal Science, 76, 14051420. doi: $10.2527 / 1998.7651405 x$.

Javanmard, A., Asadzadeh, N., Hossein Banabazi, M., Tavakolian, J., 2005. The Allele and Genotype Frequencies of Bovine Pitvitary-SpecificTranscription Factor and Leptin Gene in İranian Cattle and buffalo Populations using PCR-RFLP. Iranian Journal of Biotecnolocy., 25, 3-2.

Javanmard, A., Elyasi, G., Gharahedaghi, A.A., Nassiry, M.R., Ayazi, A., Asadzadeh, N., 2004. Polymorphism Within The Intron Region Of The Bovine Leptin Gene In Iranian Sarabi Cattle. The Joint Agriculture and Natural Resources Symposium, Tabriz Ganja, May 14-16.

Javanmard, A., Khaledi, K., Asadzadeh, N., Solimanifarjam, A.R., 2010. Detection of Polymorphisms in the Bovine Leptin (LEP) Gene: Association of a Single Nucleotide Polymorphism with Breeding Value of Milk Traits in Iranian Holstein Cattle, Journal of Molecular Genetics, 2, 10-14.

Komisarek, J, Antkowiak, I., 2007. The relationship between leptin gene polymorphisms and reproductive traits in Jersey cows. Polish Journal of Veterinary Science, 10, 193-197.

Kök, S., Vapur, G., Özcan, C., 2015. Sığır Etlerinde Mozaikleşme ile illişkili Leptin (LEP) Geni Polimorfızmleri. Türk Tarım ve Doğa Bilimleri Dergisi 2, 297-302.

Kulig, H., Kmiec, M., Wojdak-Maksymiec, K., 2010. Associations between Leptin Gene Polymorphisms and Somatic Cell Count in Milk of Jersey Cows, Acta Vet., 79, 237-242.

Liefers, S.C., Veerkamp, R.F., Pas M.F.W., Delavaud, C., Chilliard, Y., van der Lende, T., 2003. Leptin concentrations in relation to energy balance, milk yield, intake, live weight and estrus in dairy cows. Journal of Dairy Science, 86, 799-807.

Liefers, S.C., Pas, M.F.W., Veerkamp, R.F., van der Lende T., 2002. Associations between leptin gene polymorphisms and production. live weight. energy balance. feed Intake. and fertility in Holstein heifers. Journal of Dairy Science, 85, 1633-1638.

Madeja, Z., Adamowicz, T., Chmurzynska A., Jankowski, T., Melonek, J., Switonski, M., Strabel T., 2004. Short communication: effect of leptin gene polymorphisms on breeding value for milk production traits. Journal of Dairy Science, 87, 3925-3927.

Moussavi, A.H., Ahouei, M., Nassiry, M.R. and Javadmanesh, A. 2006. Association of leptin polymorphism with production, reproduction and plasma glucose level in Iranian Holstein cows. Asian-Australasian Journal of Animal Science, 19, 627-631.

Ninov, K., Ledur, M.C., Alves, H.J., Rosario, M.F., Nones, K., Coutinho, L.L., 2008. Investigation of leptin gene in broiler and layer chicken lines. Scientia Agricola. 65, 214-219

Nkrumah, J.D., Li, C., Yu, J., Hansen, C., Keisler DH, Moore, S.S., 2005. Polymorphisms in the bovine leptin promoter associated with serum leptin concentration, growth, feed intake, feeding behavior, and measures of carcass merit. Journal of Animal Science, 83, 20-28.

Özdemir M. 2011. Genetic polymorphism of leptin gene in Holstein andnativeEastAnatolian Red (EAR) cattle raised as geneticresource in Turkey. African Journal of Agricultural Research, 6, 6008-6010.

Öztaba, K., Toker, N., Ün C., Akış, I., Mengi, A., Karadağ, O., Soysal, D., 2006. Leptin Gene Allele Frequencies of Turkish Grey, South Anatolian Red and East Anatolian Red cattle. Joint Sceintific Symposium of the Veterinary Faculties of Ludwig Maximilians Universitaet München and Istanbul University. October 5-6, 2006. İstanbul, Turkey.

Pomp D., Zou, T., Clutter, A.C., Barendse, W., 1997. Rapid communication: mapping of leptin to bovine chromosome 4 by linkage analysis of a PCR-based polymorphism. Journal of Animal Science, 75, 1427. 
Rasor C.C., Thomas, M.G., Enns, R.M., Salazar, H.C., Zhang, H.M., Williams, G.L., Stanko, R.L., Randel, R.D. and Rios, J., 2002, Allelic and Genotypic Frequencies of theLeptin Gene Sau3AI Restriction Fragment Length Polymorphism and Evaluation of itsAssociation to Age-of-Puberty in Cattle in the Southwestern United States and Northern Mexico, Journal of Professional Animal Scientists, 18, 141-146.

Ünal H., 2020. Simmental ırkı sığırlarda k-kazein (CSN3) geni polimorfızmi ve bazı performans özellikleri arasındaki ilişkileri. Yüksek Lisans Tezi. Atatürk Üniversitesi, Fen Bilimleri Enstitüsü, Zootekni Anabilim Dalı, Erzurum.

\section{Tables}

Table 1 Restriction enzyme, the cutting region and fragment size of genotypes

\begin{tabular}{|llll|}
\hline RE & PCR product (bp) & Cutting region & Genotype and fragment size (bp) \\
Sau3AI & 495 & $5^{\prime}-/$ GATC-3' & AA:299/196 \\
& & & AB: $299 / 214 / 196 / 85$ \\
& & & BB: $214 / 196 / 85$ \\
\hline
\end{tabular}

Table 2 Leptin genotype and allele gene frequencies of breeds

\begin{tabular}{|lllll|}
\hline Genotype & \multicolumn{2}{c|}{ Brown Swiss } & \multicolumn{2}{c|}{ Simmental } \\
\cline { 2 - 5 } & $\mathbf{n}$ & $\%$ & $\mathbf{n}$ & $\%$ \\
\hline AA & 55 & 88,7 & 47 & 78,3 \\
\hline AB & 6 & 9,7 & 10 & 16,7 \\
\hline BB & 1 & 1,6 & 3 & 5,0 \\
\hline Allel Gene Frequence (\%) & A & B & A & B \\
\cline { 2 - 5 } & 94 & 6 & 87 & 13 \\
\hline
\end{tabular}

Table 3 LEP genotype frequencies and Hard-Weinberg genetic equilibrium test results

\begin{tabular}{|llllll|}
\hline Breed & N & Observed & Estimated & $\mathbf{X}^{2}$ test & P \\
\cline { 2 - 6 } & & AA/AB/BB & AA/AB/BB & & \\
\hline Brown Swiss & 62 & $55 / 6 / 1$ & $54,26 / 7,48 / 0,26$ & 2.44 & ns \\
\hline Simmental & 60 & $47 / 10 / 3$ & $45,07 / 13,87 / 1,07$ & 4.67 & * \\
\hline
\end{tabular}

ns: non-significant $(P>0,05), *: \quad P<0,05)$

Table 4 LEP/Sau3AI Genotypes with least squares means and standard errors for some yield traits. 


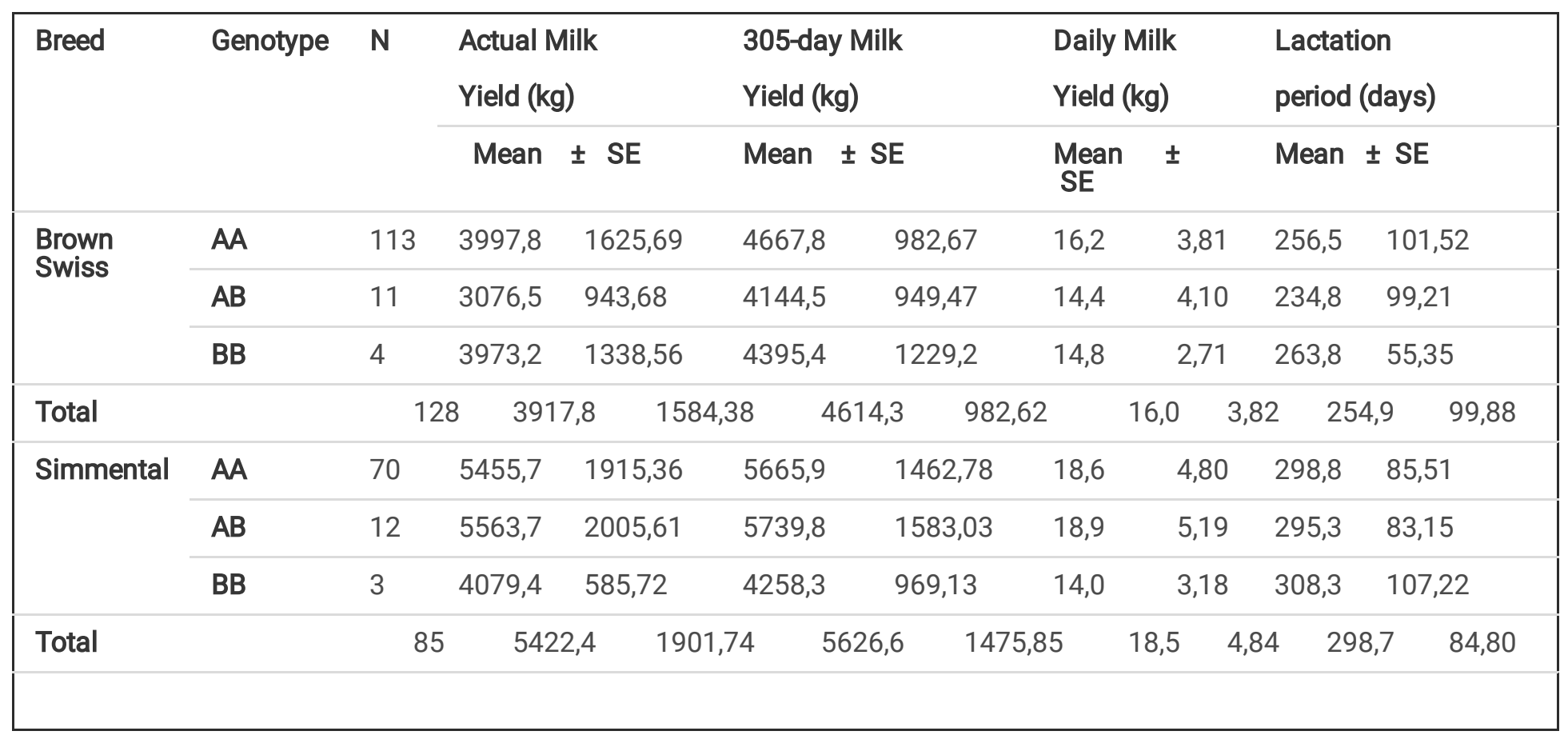

\section{Figures}

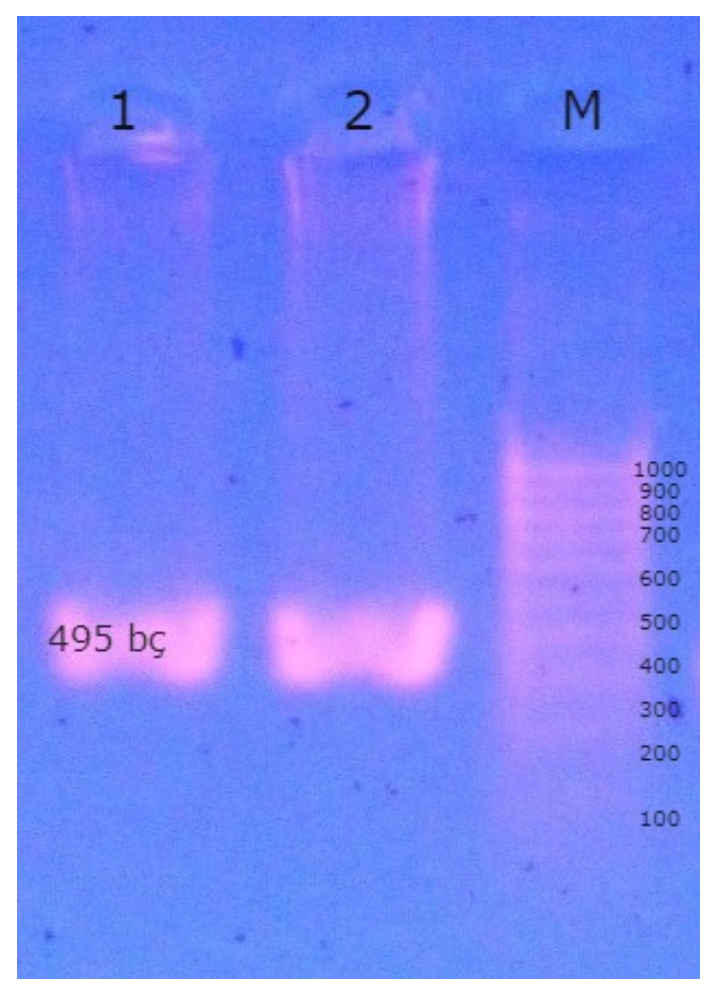

Figure 1

Agarose gel image of PCR products (M: marker,1000-100 bp; leptin PCR product: 495 bp). 


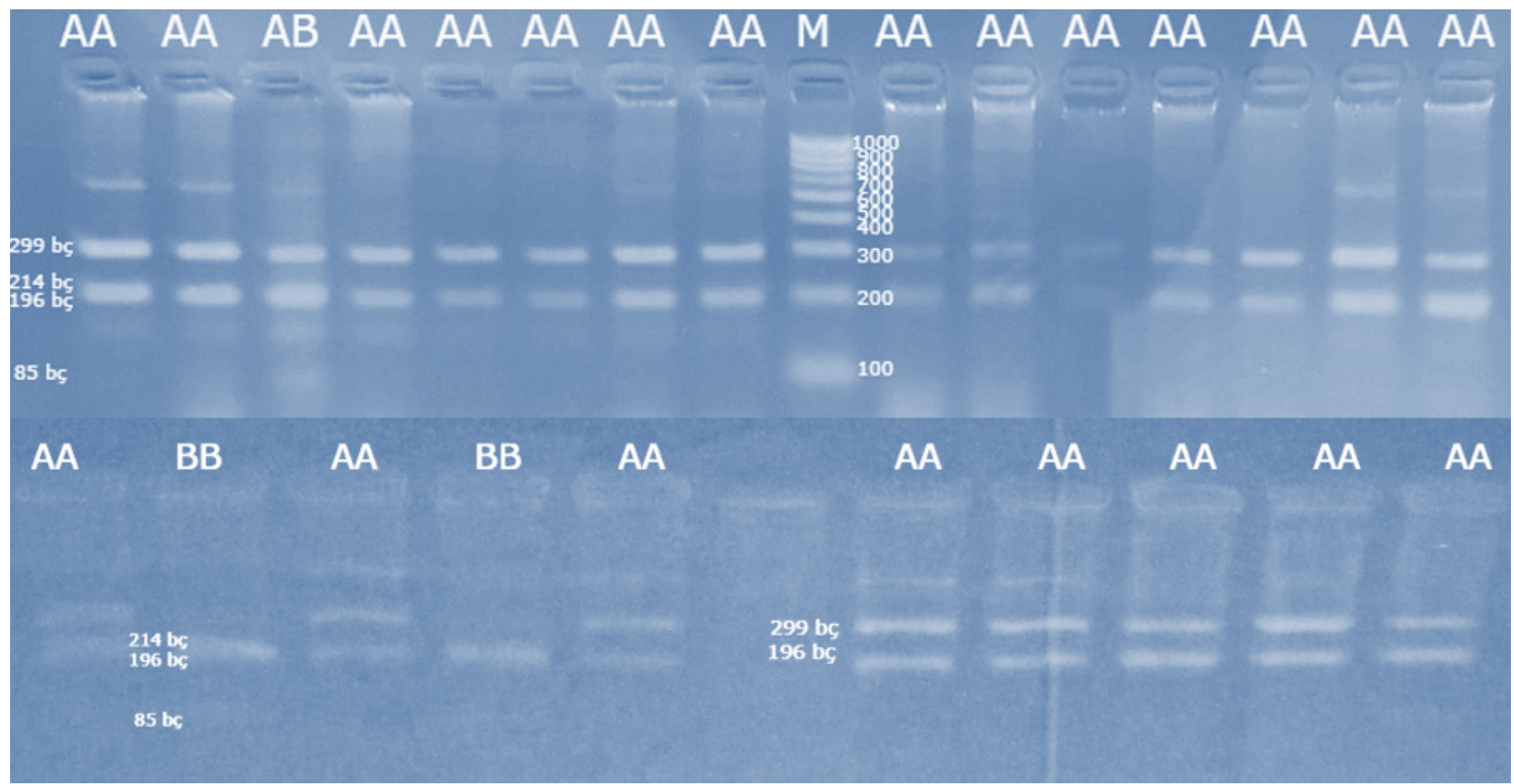

\section{Figure 2}

PCR-RFLP gel image of LEP/Sau3Al polymorphism (M:DNA marker, AA: 299/196 bp, AB: 299/214/196/85 bp, BB: 214/196/85 bp) 